\title{
Effect of Strategic Supplier Relationship Management on Internal Operational Performance of Manufacturing Firms: A Case of East African Breweries Limited, Kenya
}

\author{
Owuor Joel Onyango ${ }^{1}$, Muma Benard Onyango ${ }^{1}$, Sophia Nduta Kiruri ${ }^{1}$, Susan Njeri Karanja ${ }^{2}$ \\ ${ }^{1}$ Department of Accounting, Finance and Management Science, Egerton University, Nakuru, Kenya \\ ${ }^{2}$ College of Human Resource Development, Jomo Kenyatta University of Agriculture and Technology, Nakuru, Kenya
}

Email address:

joelowuor@gmail.com (Owuor J. O.), mumabenard@gmail.com (B. O. Muma), sophiekiruri@yahoo.com (S. N. Kiruri), susannjeri@yahoo.com (S. N. Karanja)

\section{To cite this article:}

Owuor Joel Onyango, Muma Benard Onyango, Sophia Nduta Kiruri, Susan Njeri Karanja. Effect of Strategic Supplier Relationship Management on Internal Operational Performance of Manufacturing Firms: A Case of East African Breweries Limited, Kenya. International Journal of Economics, Finance and Management Sciences. Vol. 3, No. 2, 2015, pp. 115-124. doi: 10.11648/j.ijefm.20150302.16

\begin{abstract}
It is the aim of every organization to achieve sustainability and operational excellence. For these reasons, organizations adopt various strategies. To achieve operational excellence, every functional area of the organization must be have roles to play. Supply chain operations are in particular key in enhancing operational performance. The aim of this study was to determine the effect Strategic Supplier Relationship Management on Internal Operational Performance of Manufacturing Firms. The study focused on business-supplier communication and business-supplier joint decision making. The study was grounded on three objectives; to establish the effect of buyer supplier communication on operational performance of manufacturing firms, to evaluate the influence of buyer supplier joint decisions on operational performance of manufacturing firms and to investigate the overall effect of strategic supplier relationship management on internal operational performance of manufacturing firms. This was a correlational study and both descriptive and inferential analyses were conducted. The individual parameters were analyzed using descriptive statistics (frequencies, mean, standard deviation and variance) while regression analyses was conducted to test the effect of strategic supplier relationship management on internal operational performance. The study revealed that business-supplier communication and business-supplier joint decision making both individually and jointly have positive effect on internal operational performance. This study therefore recommends that management of manufacturing firms and other organizations adopt and implement strategic supplier relationship management as one of the management strategies. In addition, the study suggests that further studies are conducted to relate other aspects of strategic supplier relationship and organizational performance such as financial, environmental and social performance.
\end{abstract}

Keywords: Strategic Supplier Relationship Management, Internal Operational Performance, East African Breweries Limited

\section{Introduction}

\subsection{Background of the Study}

Supplier relationship management is the process that defines how a company interacts with its suppliers. As the name suggests, this is a mirror image of customer relationship management (CRM). Just as a company needs to develop relationships with its customers, it also needs to foster relationships with its suppliers. The desired outcome is a win-win relationship where both parties benefit." (Supply Chain Management Institute, 2008, July) "SRM is understood as the sourcing policy-based design of strategic and operational procurement processes as well as the configuration of the supplier management." (Appelfeller, \& Buchholz, 2005). Integration of internal processes of the organization with the suppliers and customers forms the essence of the whole idea behind SCM. With the widespread use of internet, web-based systems enable organizations to form strong customer and supplier integration for inventory management, demand forecasting, customer and supplier relationship management (Frohlich \& Westbrook, 2002). Strategic suppliers/vendors are defined as those that provide high value, high complexity goods or services. The nature of 
managing successful strategic supplier relationships requires both client and supplier staff to collaborate on developing ideas that will ultimately grow into innovation and proactivity. It's not simply about the supplier delivering hard tangibles to the requirements of the client. By disregarding measurement of the qualitative component in the relationship, buyers lose the ability to gain a meaningful competitive advantage.

The descriptions of relationships are relatively abstract and vary with the discipline from which they are being researched (e.g. strategy, economics or psychology). As soon as two or more parties (i.e. organizations) associate themselves in order to fulfill a mutual business purpose a relationship is established (Szwejczewski, M., et al, 2005). Such an association leads to various joint activities, which are dependent on the specific business objective. Buyer-supplier relationships are classified as- adversarial arm's-length approach and partnerships approach (Ellram, 1991). The difference between, traditional arm's-length relationships and partner- ships is clear partnerships are closer than other types of relationship. Relationships are seen as having positive links to performance but little is known about the nature of this performance. Relationships themselves can be seen as generic; applying to all buyer-supplier exchanges. Relationships are viewed as mutual, two-way, involved exchanges between buyers and suppliers. It is apposite, therefore, to bring a relationship performance viewpoint to this key nexus of a firm's operation.

For more than a decade, there has been a large and growing interest, among academics and practitioners alike, in the value of effective supply chain management (SCM) practices. The literature suggests that a move towards to a close relationship between suppliers and customers is mutually beneficial for both parties. This notion has been widely accepted among original equipment manufacturers (OEMs) in the U.S. As a result, the leading OEMs have reduced their supplier base in recent years and reportedly developed closer relationships with a selected few in the form of strategic alliances or partnerships (McCutcheon \& Stuart 2000; Johnston et al. 2004; Narayandas \& Rangan 2004; The Economist 2006). Buyer supplier relationships are commonly evaluated as supply base reduction, communication and long-term relationship (Buvil \& Haugland, 2005; van Denlu \& Verder Vaart, 2004). Supplier relationship management (SRM), a subset of supply chain management, is concerned with understanding who your most important suppliers are and how you can focus your time and energy on creating and maintaining more effective strategic relationships with them.

An effective SRM solution contains essential components such as ranking, rating and optimization that allow a firm to reduce its supply base and overall costs. Ultimately, an effective SRM solution gives an organization a complete edge by allowing it to; reduce direct and indirect costs and improve bottom line profitability, understand what is being bought and from whom, minimize the risk of supply chain disruption, select the best supplies to again advantage over competitors, streamline the supply chain management process by collaborating with business units across the enterprise and assuring that the organization's Resources are prioritized on the most critical suppliers (Berkowitz, 2004). Performance on the other hand is how efficient and effective supplier relationship management solution help in achieving organizational objectives (Lawer, 2001).

Performance is conceptualized as buyer's purchasing cost, innovation and financial performance , supplier's operational and strategic performance and dynamic quality performance (Costen \& Felder, 2005; Humpreys, Li \& chan, 2004; Poutray \& Ohen, 2005; Benton, 2004; Pressey \& Tzokasi, 2004; Sanders, 2005). In the recent study by (Lahiri, Kedia \& Mukherjee, 2011) identified that higher partnership quality between the buyer and the supplier leads to increased performance benefit and management capability of the firms. Close relationship means risks and rewards should be share by the channel members. They also should be willing to sustain the relationship for a long period of time (Shin, Collier, \& Wilson, 2000). Hence, when we managing a supply chain network, it is essential to recognize who are the partners of the supply chain for resulting smooth information flow, inventory control and operation performance. Firms that rely on high quality partnerships with suppliers are better prepared to adapt to unforeseen changes, identify and produce better solutions to organizational problems. Besides, it will help to reduce monitoring costs which results improvement in the economic outcomes (Ryu, Park, \& Soonhong, 2007).

To leverage the purchasing function into a more strategic level the external initiatives, such as supply base optimization and buyer-supplier relationships, may have to be complemented with more internally oriented activities (Narasimhan \& Das, 2001). As the purchasing function has moved away from being a truly cost-saving function (Cousins \& Spekman, 2003) a greater focus has been put on how the purchasing strategy fits into the rest of the company's strategy and activities. This has been referred to as purchasing integration and can be defined as "the integration and alignment of strategic purchasing and goals with that of the firm" (Narasimhan \& Das, 2001). This requires that purchasing participates in the strategic planning process, that purchasing has access to strategic information and that important purchasing decisions are coordinated with other strategic decisions of the firm (Narasimhan \& Das, 2001).

This will make it possible for the purchasing manager to regularly ensure that the current activities are aligned with the company's strategic plans. East African Breweries Limited (EABL) is East Africa's leading branded alcohol beverage business with an outstanding collection of brands that range from beer, spirits and adult non-alcoholic drinks (ANADs) reaffirming our standing as a total adult beverage (TAB) company. With breweries, distilleries, support industries and a distribution network across the region, the group's diversity is an important factor in delivering the 
highest quality brands to East African consumers and long-term value to East African investors. As a consumer driven business EABL takes time to study the market and understand consumer needs and wants as well as how best to satisfy them. EABL's diversity as a robust regional company is revealed in its subsidiaries: Kenya Breweries Limited, Uganda Breweries Limited, Serengeti Breweries Limited, United Distillers Vintners, Central Glass Industries, East African Maltings Limited and East African Breweries International. With this vast distribution of markets, knowledge and manpower 'celebrating life every day, everywhere' is EABL's way of life.

KBL has been a leading brewer in Kenya since it began operations in 1922. The KBL Brewery is located in Ruaraka, near the capital Nairobi. This state-of-the-art facility has generated major savings in cost of production as well as improving quality. Key brands include: Tusker Lager which is the flagship brand, Tusker Malt Lager, Pilsner, White Cap, White Cap Light, Senator, Guinness, Allsopps and President Lager. The company deals with a fairly large number of suppliers. In attempts to cut costs and enhance efficiency in its operations, the Company recognizes the need for affective supplier relationship management.

Monczka et al, (2009) opine that the main idea of the relationship between buyer and supplier is to create a win-win situation for both the buyer and supplier, compared to the traditional approach where the buyer had the power and could play the suppliers against each other just to minimize cost. The collaboration should enable for example mutual cost sharing, joint improvement efforts, conflict-resolution and better communication. It is against this background that the study focused on the effect of strategic supplier relationship management on operational performance at the East African Breweries Limited.

\subsection{Significance of Study}

The study intended to develop an understanding of the complex supplier relationship management and suggested ways through which operational efficiency can be enhance through supplier relationship. This information is very useful to management, especially of manufacturing/processing firms. This study is considered to be beneficial to manufacturing firms as it will form a point of reference towards promoting their operational performance through strategic supplier relationship management. The study is also beneficial to upcoming researchers who will be interested in conducting studies in this or related field. This is due to the fact that the findings of this study will form part of rich literature on the strategic supplier relationship and operational performance.

\subsection{General Objective}

The general objective of this study was to investigate the effects of strategic supplier relationship management on internal operational performance of manufacturing firms. The specific objectives were;

1. To establish the effect of buyer supplier communication on operational performance of manufacturing firms

2. To evaluate the influence of buyer supplier joint decisions on operational performance of manufacturing firms

3. To investigate the overall effect of strategic supplier relationship management on internal operational performance of manufacturing firms

\subsection{Research Hypothesis}

$\mathrm{HO}_{1}$ : Buyer supplier communication has no effect on operational performance of manufacturing firms

$\mathrm{HO}_{3}$ : Buyer supplier joint decisions has no influence on operational performance of manufacturing firms

$\mathrm{HA}_{3}$ : Strategic supplier relationship management on internal operational performance of manufacturing firms

\subsection{Conceptual Framework}

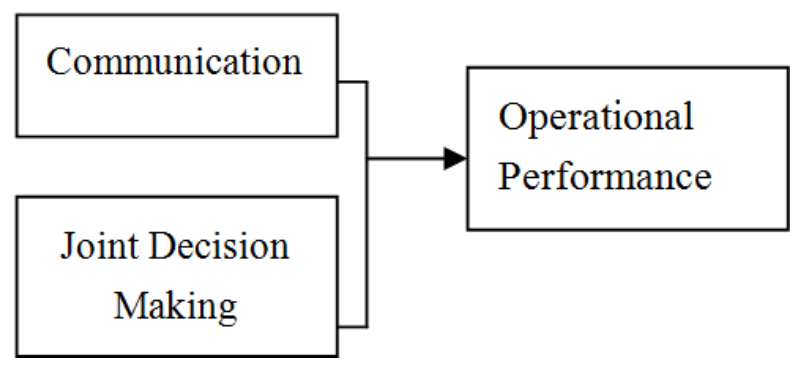

Figure 1. Conceptual Framework.

\section{Literature Review}

\subsection{Buyer/Supplier Communication and Operational Performance}

Collaboration in inter-organizational relationships is often hampered by poor communication (Dyer et al. 2001). According to (Amabire, 2001) organizations must set up procedures such as communication and coordination of processes for collaboration. He further opine that Not all communication mechanisms however are equally effective or efficient. A continuum of media richness has been proposed for various modern modes of communication ranging from person to person mettings for standardized data transfer, such as electronic data interchange (EDI).

Communication is approached on the information systems level. Computer-based information systems are used to process and disseminate information within and between organizations and thus support the accomplishment of the defined processes (Laudon, 2006). Analytical SRM (white rounded squares) aim at storing, analyzing, and applying knowledge about suppliers and personnel dedicated to manage the supplier's relationship. For this, typically performance management and decision support tools (e.g. business intelligence, on-line analytical processing, statistical tools, data warehousing, data mining) are used. The purpose of collaborative SRM (light gray rounded squares) is to improve the quality of supplier collaboration, and, as a result, increase supplier performance and reliability. E-Collaboration tools 
(e.g. collaborative forecasting and planning), E-Contract management tools, E- Auctions, E-Tendering, and E-RFx tools (e.g. electronic request for information, quotation, and proposal) fall into this category. Operational SRM (dark gray rounded squares), commonly referred to as E-Procurement, includes all necessary tools for ordering and conclusion of a contract such as payment, invoice verification. Typical examples are plan-driven purchasing and desktop purchasing tools, E-Payment, supplier self-service, and supplier portals.

Laudon, (2006) further reported that alongside analytical, collaborative, and operational SRM, other tools are needed (dashed rounded squares) to support activities, which are not in the core of procurement. For instance, search engines to retrieve all kind of internal and external information related to sourcing, inventory control systems to build the crucial bridge to the logistics department and requester of goods, business process modeling and enterprise architecture solutions for visualizing, simulating and analyzing different structural aspects of the purchasing department, personnel administration systems for managing workforce related information, finance and controlling systems to define targets and supervise the achievement of objectives, and enterprise content management systems to dispense all kind of documentation.

\subsection{Buyer Supplier Joint Decisions on Operational Performance}

Despite the great interest in supply chain partnerships, however, the authors are not aware of any research that measures relationships ' cooperative activities along with their associated outcomes or relates to the outcomes of the contingent variables unique to each supplier and buyer. (Narasimhan et al 2001). Joint decision is one of the most sophisticated forms of information exchange, requiring high levels of trust and transparency. The joint decision making process typically involves the maintenance of information flow, the assignment of resources, problem solving, the preparation of detailed activity reports, inter-organizational strategic decision making and the preparation of future plans (Gulati et al 1994).

Like most joint decisions, between a supplier and manufacturer, joint decision making is a form of non-equity governance agreed upon by both parties to pursue their mutual interests without the cost of direct ownership of activity (Joshi \& Stum, 1999). Joint decision making is required in areas such as; joint collaborative planning initiatives which have been reported to improve the performance of order entry and deliver (Barrat \& Oliveria, 2001); joint decision making regarding quality and process improvement initiatives, which have long been recognized as an area where joint decision making is required (Burt, 1989); joint decision making about cost improvements, which is usually associated with procurement activities (Dyer, 1996)

The outcomes of the joint decision making process (i.e the output) is measured as the satisfaction with the efforts as perceived by the purchasing organization. The buyer's satisfaction has a direct and indirect component. The direct effect of joint decision making activities on satisfaction reflects whether the purchasing function core requirements for secure supply with good quality at good price is satisfied (Leenders eta al, 2002). The direct effect for the buyer is a sign of whether the buyer's internal customers (e.g. engineering and operations) are satisfied with the outcomes, including the contribution of innovative solutions to their problems. Any measure of joint decision making must accommodate a range of organizational objectives.

An accepted paradigm in the supply chain management (SCM) literature views the ideal relationships between supplier and customer firms as cooperative for mutual benefits (Harland, Knight \& Cousins, 2004) for a review of supply chain relationship perspectives held by different business disciplines). Cooperation often arises in the context of firms' specific needs (cost reduction or value addition) and "unfolds through ongoing interactions" between firms (Heide \& Miner, 1992). Domains of interactions where cooperation takes place include information sharing and joint decisions. Information sharing can be defined as the degree to which each party discloses information that may facilitate the other party's activities (Frazier et al. 1988; Heide \& Miner 1992; Sousa 2003; Johnston et al. 2004). Joint decisions can be defined as the degree to which each party penetrates the other party's organizational boundaries, and include joint efforts to improve, for example, production costs, demand forecasts and product designs (Frazier et al. 1988; Heide \& John 1990; Heide \& Miner 1992; Jap 1999; Sousa 2003; Johnston et al. 2004).

\subsection{Resource Dependency Theory}

Resource dependence theory takes the view that a business relationship is a social exchange of critical resources with mutual dependency among the exchange partners. Thus, the survival and growth of organizations largely depend on the ability to secure critical resources from the external environment (Emerson 1962; Pfeffer \& Salancik 1978; Casciaro \& Piskorski 2005). But a relationship between organizations is not free. Transaction cost analysis (TCA) suggests that every transaction has a cost. These costs are incurred for adaptation, performance evaluation and safeguarding, and are associated with uncertainty, opportunism, and transaction specific assets (TSAs) invested in the relationship (Williamson, 1996; Rindfleisch \& Heide 1997). Transaction specific assets refer to the assets specialized to service the particular needs of the exchange parties (Williamson 1996). Firms invest in TSAs in order to create additional value from an exchange above what standard product and service offerings can do (Ghosh and John, 1999). Examples of TSAs include the development of idiosyncratic knowledge, the provision of dedicated human resources and training, and capital investment in specialized equipment and facility improvement (Williamson, 1996)

Although resource dependence theory and transaction cost analysis depart from different points of view (sociology and new institutional economics, respectively), they have something in common. While resource dependence theory 
focuses on ex ante mutual dependence between exchange partners due to critical resources, transaction cost analysis assumes that two parties are initially independent but develop bilateral dependence ex post due to relationship-specific assets invested over the course of the relationship (Heide 1994 ; Casciaro \& Piskorski 2005). Despite these different views, however, both theories recognize the existence of interdependency between exchange partners and the importance of securing valued resources from environmental and behavioral uncertainty (Heide, 1994).

Specifically, based on utilitarian assumptions of self-interested behaviors of exchange partners, transaction cost analysis argues that TSAs raise the cost of safeguarding against a behavioral uncertainty of an exchange partner such as an opportunistic behavior where one party may exploit the other for unilateral benefits (Heide \& John 1990; Heide 1994; Rindfleisch \& Heide 1997; Bensaou \& Anderson 1999; Ghosh \& John 1999, 2005). Being unique to a relationship, and possessing little or no value upon the relationship termination, TSAs are often viewed as "valuable but vulnerable" investments (Ghosh \& John 1999; Wathne \& Heide 2004; Ghosh \& John 2005).

Combining the resource and transaction cost perspectives into a strategic point of view, Ghosh \& John (1999) proposed a governance value analysis (GVA) framework that links resources, positioning strategy, TSAs and governance. They argue that a firm creates potential market value through a unique positioning and can claim those values through a competitive advantage based on firm-specific resources. In an effort to achieve competitive advantage in the market, firms align themselves with exchange partners (i.e., customers and suppliers) and create joint values, such as cost reduction and/or value addition, through investments in TSAs.

While creating maximum values from the market, (Ghosh \& John 2005) argue that firms should safeguard their share of values jointly created as well as their investments in TSAs against opportunism through strategic selection of relationship governance. For example, the authors found, in a later study on industrial alliances, that OEMs - given a high level of specific investments - achieve a high level of cost reduction from less flexible contracts with their suppliers while achieving a high level of end-product enhancement from more flexible contracts (Ghosh \& John 2005). Based on these findings, they suggest that OEMs take different "governance value engineering" approaches to supplier relationship management depending on their primary pursuit of strategic outcomes (i.e., cost reduction vs. product enhancement).

\section{Research Methodology}

\subsection{Research Design}

This study adopted a correlational research design. It was a cross sectional study conducted at one point in time.

\subsection{Target Population}

The population is an aggregate of subjects who have shared characteristics. In other words, it is a set which includes all measurements of interest to the researcher (Schoenherr \& Tummala, 2007). According to Kasomo (2007), target population should be explicitly and unequivocally defined. The study targeted the 54 employees stationed at the procurement department of the East African and Breweries Limted. All the respondents were derived from the procurement departments of the company. The target population was considered appropriate since they were perceived to be conversant with supplier relationship matters as a result of their professional qualification and experience in their respective positions.

\subsection{Sampling Techniques}

The sample frame was comprised of 54 employees at EABL. Consequently, the various officers in charge of procurement function in the firm were included in the sample frame as they were perceived to be conversant with the procurement matters with regard to their knowledge and experience with the function.

Table 3.1. Sampling Frame.

\begin{tabular}{lll}
\hline Section & Number & Percentage \\
\hline Expedition & 14 & 26 \\
Procurement & 19 & 35 \\
Warehouse officer & 8 & 15 \\
Inventtory management officer & 13 & 24 \\
TOTAL & 54 & $100 \%$ \\
\hline
\end{tabular}

Source: Human Resource (EABL, 2015)

A sample is a smaller (but hopefully representative) collection of units from a population used to determine truths about that population (Field, 2005). There are 54 employees at EABL hence a census study was conducted among all the employees.

\subsection{Data Collection Instrument}

The study used questionnaire to obtain primary data. This is because questionnaires are fast, cheap and can be self-administered, according to (Mugenda \& Mugenda, 2003). The instrument was used since it was considered reliable and capable of obtaining detailed information on the topic of study. The questionnaire contained closed ended questions for the purpose of giving the respondents an easy time to provide more accurate information. A 5 point Linkert scale where 1 represents the least important response and 5 represents the most important response was employed. In order to minimize on errors, delays and bias, there was a few open ended questions allowing respondents to express personal opinion. The study also utilized secondary data from other publications where it was considered necessary.

Prior to embarking on the main study, the researcher carried 
out a pilot study with the aim of verifying both the reliability and validity of the research instruments. The pilot study involved collecting data from $10 \%$ (5 respondents) who were randomly selected from the Population comprising Keroche Breweries Limited, Naivasha. These respondents were not part of the main study. Reliability of the instrument was determined by use of Cronbach alpha. In the event the instrument attained alpha $0.7(\alpha \geq 0.7)$ it was to be deemed reliable.

\subsection{Data Collection Procedure}

Permission was sought from the respondents to conduct the study through the use of the introductory letter from JKUAT. The researcher then identified the specific respondents and issued them with questionnaires which they filled at their convenience but within the research schedule. The questionnaires were then picked after two days for analysis.

\subsection{Data Processing and Presentation}

Kothari (2004) defines analysis as the computation of certain indices or measures along with searching for patterns of relations that exist among data groups. It is made up of qualitative statistics; analyzing information in a systematic manner in order to come to a useful conclusion and recommendation. Data screening was conducted to ensure the data was properly recorded and that the distribution of variables used in the analysis were normal. The statistical method for this study was descriptive and inferential statistics. Data analysis was done using Statistical Package for Social Sciences computer software (SPSS) version 21. Descriptive statistics such as mean and standard deviation were used to present the various characteristics for data sets. For this kind of study, descriptive analysis is the best and has been supported by such scholars as Cooper and Schindler (2003). Inferential statistics such as Karl Pearson Correlation were used to apply a one-on-one relationship between the independent variables and the dependent variable, while holding all other factors constant. This formed the basis for rejecting or accepting the null hypothesis.

\section{Discussion}

\subsection{Reliability Test Results}

In order to ascertain the reliability of the research instrument majorly the questionnaire, a pilot test was conducted and data analyzed using Cronbach's Alpha. The findings were as follows;

Table 4.1. Pilot Test Results.

\begin{tabular}{lll}
\hline Items & Cronbach's Alpha & N of Items \\
\hline Supplier communication & 0.804 & 12 \\
Strategic material sourcing & 0.759 & 8 \\
Buyer supplier joint decisions & 0.692 & 5 \\
SRM and operational performance & 0.701 & 5 \\
Alpha $(\alpha)$ & 0.739 & 30 \\
\hline
\end{tabular}

The mean of Cronbach's alpha value obtained was 0.739 . This result was $>0.7$ which was considered the accepted $\alpha$ value. The research instrument was therefore considered reliable to achieve the desired results of the study. The Cronbach's Alpha yielded a reliability coefficient greater than 0.7 and was therefore adopted for the final study.

\subsection{Effect of Buyer Supplier Communication on Operational Performance}

The study sought to investigate the effect of buyer supplier communication on operational performance. The respondents were asked to indicate the extent to which they agreed with the various variables under the objective and findings were as follows;

Table 4.2. Buyer supplier communication and operational performance.

\begin{tabular}{|c|c|c|c|c|c|}
\hline & $\mathbf{N}$ & Minimum & Maximum & Mean & Std. Deviation \\
\hline Communication enhances coordination between supply chain partners & 51 & 4 & 5 & 4.86 & .348 \\
\hline Use of communication systems to process and disseminate information & 51 & 3 & 5 & 4.57 & .539 \\
\hline Frequent sharing of information with suppliers & 51 & 3 & 5 & 4.65 & .559 \\
\hline Information sharing enhances supplier relationship & 51 & 3 & 5 & 4.51 & .579 \\
\hline $\begin{array}{l}\text { Collaborative supplier relationship management improve supplier } \\
\text { performance and reliability }\end{array}$ & 51 & 2 & 5 & 4.49 & .644 \\
\hline Valid N (list wise) & 51 & & & & \\
\hline
\end{tabular}

Table 4.2 revealed that respondents strongly agreed that communication enhances coordination between supply chain partners (mean $=4.86)$, that communication systems were used to process and disseminate information (mean=4.57), that there was frequent sharing of information by suppliers (mean=4.65) and that information sharing enhances supplier relationship as indicated by a mean of 4.51. Further, majority strongly agreed that information sharing promotes trust and mutual understanding. On the other hand, it was agreed that collaborative supplier relationship management improve supplier performance and reliability as indicated by a mean of 4.49 . 


\subsection{Information Communicated with Suppliers}

To effectively assess the effect of buyer supplier communication, the study sought to establish the nature of information exchanged between the buyer and the suppliers. The findings were as follows;

Table 4.3. Exchanged Information with Suppliers.

\begin{tabular}{llllll}
\hline & N & Minimum & Maximum & Mean & Std. Deviation \\
\hline Production schedules & 51 & 2 & 5 & 4.63 & .720 \\
Distribution schedules & 51 & 1 & 5 & 4.08 & .977 \\
Inventory levels & 51 & 2 & 5 & 4.35 & .796 \\
Sales data and forecasts & 51 & 1 & 5 & 3.92 & 1.093 \\
Delivery plans of supply chain members & 51 & 2 & 5 & 4.33 & .816 \\
Performance metrics & 51 & 1 & 5 & 4.02 & 1.049 \\
Valid N (list wise) & 51 & & & \\
\hline
\end{tabular}

Table 4.3 indicated that production schedules were the major information shared between the buyer and the suppliers as indicated by a mean of 4.63 . It was also agreed $(m e a n=4.35)$ that inventory levels were also shared. Further, the table revealed that respondents agreed that sales data and forecasts (mean=3.92), delivery plans of supply chain members (mean=4.33) and performance metrics (mean=4.02) were shared between the firm and its suppliers.

\subsection{Influence of Buyer Supplier Joint Decisions On Operational Performance}

Respondents were also asked to assess the influence of buyer supplier joint decisions on operational performance and results were as follows;

Table 4.4. Buyer supplier joint decisions and operational performance.

\begin{tabular}{llllll}
\hline & N & Minimum & Maximum & Mean & Std. Deviation \\
\hline Cost improvement & 51 & 4 & 5 & 4.80 & .401 \\
Joint collaboration planning initiatives & 51 & 3 & 5 & 5.49 & .612 \\
Product design and redesign & 51 & 1 & 5 & 4.24 & 1.031 \\
Quality and process improvement initiatives & 51 & 1 & 5 & 3.94 & 1.207 \\
Information is shared with suppliers to great extent at EABL & 51 & 1 & 5 & 3.50 & 1.206 \\
Valid N (list wise) & 51 & & & & \\
\hline
\end{tabular}

Table 4.4 indicated that majority of the respondents strongly agreed $(m e a n=4.80)$ that buyer supplier joint decisions enhances cost improvements in relations to operational performance. It was also agreed upon $($ mean $=4.49)$ that joint collaboration planning initiatives characterize buyer supplier joint decisions. Consequently, it was agreed (mean $=4.24)$ upon by majority of the respondents that buyer supplier joint decisions was necessary in product design and redesign. In addition, it was reported that buyer supplier joint decisions were geared towards quality and process improvement as indicated by a mean of 3.94 . Respondents agreed (mean $=3.50$ ) that information is shared with suppliers to a great extent at EABL.

\subsection{Effective Supplier Relationship Management and Operational Performance}

The study sought to indicate the extent to which they agreed to the relationship between supplier relationship management and operational performance. The respondents were asked to agree on the various factors describing the success of supplier relationship management in enhancing operational performance. The findings were as follows;

Table 4.5. Supplier Relationship Management (SRM) and Operational Performance.

\begin{tabular}{|c|c|c|c|c|c|}
\hline & $\mathbf{N}$ & Minimum & Maximum & Mean & Std. Deviation \\
\hline Smooth information flow & 51 & 3 & 5 & 4.65 & .522 \\
\hline Better adaption to unforeseen changes & 51 & 1 & 5 & 4.49 & .834 \\
\hline Identify and production of better solutions to organizational problems & 51 & 3 & 5 & 4.53 & .703 \\
\hline Reduced monitoring costs & 51 & 1 & 5 & 4.37 & .799 \\
\hline Conflict resolution and better communication & 51 & 3 & 5 & 4.55 & .702 \\
\hline Valid N (list wise) & 51 & & & & \\
\hline
\end{tabular}

According to table 4.5 , it was revealed that majority of the respondents strongly agreed that effective supplier relationship management ensures smooth information flow (mean=4.65) and better adaption to unforeseen changes (mean=4.49). In addition, the table also showed that effective supplier relationship management helps in identifying and 
production of better solutions to organizational problems thereby enhancing operational performance. This was indicated by a mean of 4.53. It was also revealed that majority of the respondents agreed (mean=4.37) that effective supplier relationship management helps in reducing monitoring costs (mean=4.37) and that effective supplier relationship management helps in conflict resolution and better communication between the buyer and the supplier.

\subsection{Regression Analysis}

Table 4.6. Model Summary.

\begin{tabular}{lllll}
\hline Model & R & R Square & Adjusted R Square & Std. Error of the Estimate \\
\hline 1 & $.432^{\mathrm{a}}$ & .187 & .153 & 2.19510 \\
a. Predictors: Communication, Joint Decision & & & \\
\hline
\end{tabular}

From table 4.6, The $\mathrm{R}$ square value of 0.187 reveals that the independent supplier communication management and supplier relations management affect operational performance up to 18.7 percent. The changes in operational performance can be explained up to 18.7 percent by changes in supplier communication management and supplier relations management.

\subsection{ANOVA Test}

Table 4.7. ANOVA Table.

\begin{tabular}{|c|c|c|c|c|c|c|}
\hline Model & & Sum of Squares & Df & Mean Square & $\mathbf{F}$ & Sig. \\
\hline \multirow{3}{*}{1} & Regression & 53.067 & 2 & 26.533 & 5.507 & $.007^{\mathrm{b}}$ \\
\hline & Residual & 231.286 & 48 & 4.818 & & \\
\hline & Total & 284.353 & 50 & & & \\
\hline \multicolumn{7}{|c|}{ a. Dependent Variable: Internal Operational Performance } \\
\hline \multicolumn{7}{|c|}{ b. Predictors: Communication, Joint Decision } \\
\hline
\end{tabular}

ANOVA test was conducted to test the significance level of the entire model. The significance value of 0.007 was obtained. Since the value is less than 0.05 , it was concluded that supplier communication and supplier relations management jointly have statistically significant positive effect on operational performance. This implies that organizations that implement supplier communication management and joint decisions enjoy better operational performance.

\subsection{Table of Co-Efficient}

Table 4.8. Table of Coefficients.

\begin{tabular}{|c|c|c|c|c|c|}
\hline \multirow{2}{*}{ Model } & \multicolumn{2}{|c|}{ Unstandardized Coefficients } & \multirow{2}{*}{$\begin{array}{l}\text { Standardized Coefficients } \\
\text { Beta }\end{array}$} & \multirow{2}{*}{$\mathbf{t}$} & \multirow{2}{*}{ Sig. (p) } \\
\hline & B & Std. Error & & & \\
\hline (Constant) & 13.126 & 4.753 & & 2.762 & .008 \\
\hline Communication & .453 & .149 & .396 & 3.042 & .004 \\
\hline Joint Decision & -.147 & .111 & -.172 & -1.323 & .192 \\
\hline
\end{tabular}

Table 4.8 reveals a significance value of 0.004 and 0.192 for supplier communication management and buyer supplier joint decision making. Since the $\mathrm{p}$ value for supplier communication is less than 0.05 while the significance value for joint decision making $(0.192)$ was more than 0.05 . This implies that supplier communication management and supplier relations management are predictors of operational performance. However, individually, the effect of joint communication is not statistically significant. The beta values of buyer supplier joint decisions and supplier communication values of 0.453 and -0.147 implies that the model of the study will be

$$
Y=13.126+0.453 x_{1}-0.147 x_{2}
$$

Where $\mathrm{x}_{1}$ and $\mathrm{x}_{2}$ are buyer supplier joint decision making and supplier communication management respectively

\section{Conclusions and Recommendations}

The results of this study revealed that buyer supplier joint decisions and supplier communication management have positive effect on internal operational performance of manufacturing firms in Kenya. The study further revealed that the effect was statistically significant. This implies that organizations that have well managed supplier communication systems, implement buyer supplier joint decisions and that have improved customer relations are likely to enjoy improved internal operational performance. Improved supplier relations enhance supplier performance 
which in turn enhances internal operations performance. Similarly, effective communication system improves flow of information between the organizations and suppliers improving operational performance. The study therefore recommends that management of manufacturing organizations enhance communication systems and develop lasting relations with suppliers. A dedicated information system may be used to provide real time flow of information as well as achieve enhanced relations between the suppliers and the organization.

\section{References}

[1] Adams, J., Khoja, F., \& Kauffman, R. (2012). An empirical study of buyer-supplier relationships within small business organizations. Journal of Small Business Management, 50(1), 20-40.

[2] Appelfeller, W., \& Buchholz, W. (2005). Supplier relationship management. Strategie, Organisation und IT des modernen Beschaffungsmanagements, 2.

[3] Berkowitz, D., et al (2004). Performance Based Logistics. Center for the Management of Science and Technology, Huntsville, AL.

[4] Boran, F., et al (2009). A multi-criteria intuitionistic fuzzy group decision making for supplier selection with TOPSIS method. Expert Systems with Applications, 36(8), 11363-11368.

[5] Burgess, K., Singh, P., \& Koroglu, R. (2006). Supply chain management: a structured literature review and implications for future research. International Journal of Operations \& Production Management, 26(7), 703-729.

[6] Casciaro, T. and Piskorski, M.. (2005). "Power Imbalance, Mutual Dependence, and Constraint Absorption: A Closer Look at Resource Dependence Theory." Administrative Science Quarterly 50(2): 167-199.

[7] Choi, T.,., and Hartley, J., (1996), "An Exploration of Supplier Selection Practices across the Supply Chain", Journal of Operations Management, 14(4): 333-343.

[8] Cigolini, R., et al, (2004). A new framework for supply chain management: conceptual model and empirical test. International Journal of Operations \& Production Management, 24(1), 7-41.

[9] Cooper, D. \& Schindler, P. (2000). Business Research Methods (8th Ed) McGraw-Hill: New York.

[10] Cortis, A., \& Berkowitz, B. (2005). Computing "anomalous" contaminant transport in porous media: The CTRW MATLAB toolbox. Groundwater, 43(6), 947-950.

[11] Cousins, P., \& Spekman, R. (2003). Strategic supply and the management of inter-and intra-organisational relationships. Journal of Purchasing and Supply Management, 9(1), 19-29.

[12] Degraeve, Z., Labro, E., \& Roodhooft, F. (2000). An evaluation of vendor selection models from a total cost of ownership perspective. European Journal of Operational Research, 125(1), 34-58.

[13] Dyer, J., (1997), "Effective Inter-firm Collaboration: How
Firms Minimize Transaction Costs and Maximize Transaction Value", Strategic Management Journal, 18(7): 535-556.

[14] Ellram, L., and Carr, A., (1994), "Strategic Purchasing: A History and Review of the Literature", International Journal of Purchasing and Materials Management, 30(2): 10-19 European Journal of Operational Research, 43(2): 119-135.

[15] Emerson, R.. (1962). Power-dependence relations. American sociological review, 31-41.

[16] Field A. (2005) Discovering Statistics using SPSS 2nd Edition, London: Sage

[17] Frohlich, M. \& Dixon, J. (2002). "A Taxonomy of Manufacturing Strategies Revisited." Journal of Operations Management 19(5): 541-558

[18] Ghosh, M. and John, G. (1999). "Governance Value Analysis and Marketing Strategy." Journal of Marketing 63(4): 131-145.

[19] Ghosh, M. \& John, G. (2005). "Strategic Fit in Industrial Alliances: An Empirical Test of Governance Value Analysis." Journal of Marketing Research 42(3): 346-357.

[20] Harland, C., \& Knight, Cousins (2004). 'Supply Chain Relationships'. Supply Chains, Concepts, Critiques and Futures, 209-227.

[21] Hartman, A., Sifonis, J., (2000), De Netgerichte Organisatie, Academic Service, Schoonhoven.

[22] Heide J., \& Stump R., (1994), Performance Implications of Buyer-Supplier Relationships in Industrial Markets, Journal of Business Research, 32 (57-66)..

[23] Humphreys P., Li W., Chan L., (2004), The impact of supplier development on buyer-supplier performance, The International Journal of Mangement Science, 32 (131-143).

[24] Ian S. \& McCutcheon, D. (2000). The manager's guide to supply chain management. Business Horizons, 43(2), 35-44.

[25] Johnston, D., et al, (2004). "Effects of Supplier Trust on Performance of Cooperative Supplier Relationships." Journal of Operations Management 22(1): 23-38.

[26] Kasomo, D. (2007), Research Methods in Humanities and Education, Eldoret; Zapf Chancery.

[27] Koh, S., et al (2006). The impact of supply chain management practices on performance of SMEs. Industrial Management \& Data Systems, 107(1), 103-124.

[28] Kothari, C., (2004), Research Methodology- Methods and Techniques, New Delhi, Wiley Eastern Limited.

[29] Krause, D., (1999), "The Antecedents of Buying Firms" Efforts to improve Suppliers", Journal of Operations Management, 17(2): 205-224.

[30] Laudon, K. C., \& Traver, C. (2007). E-commerce. Pearson/Addison Wesley.

[31] Lawer, C., \& Knox, S. (2004). Reverse marketing, consumer value networks and the new brand intermediaries. In Evolution of Supply Chain Management (pp. 203-225). Springer US.

[32] Mugenda, O. \& Mugenda, A. (2003). Reaserch Methods; Quantitative and Qualitative. Nairobi: Oxford University Press. 
[33] Narasimhan, R., \& Das, A., (1999a), “An Empirical Investigation of the Contribution of Strategic Sourcing to Manufacturing Flexibilities and Performance", Decision Sciences, 30(3): 683-718. Quarterly, March: 27-37.

[34] Narayandas, D. \& Rangan, V. (2004). "Building and Sustaining Buyer-Seller Relationships in Mature Industrial Markets." Journal of Marketing 68(3): 63-77.

[35] Prahinski, C., \& Benton, W. (2004). Supplier evaluations: communication strategies to improve supplier performance. Journal of operations management, 22(1), 39-62.

[36] Sanders, N. (2005). IT alignment in supply chain relationships: A study of supplier benefits. Journal of Supply Chain Management, 41(2), 4-13.

[37] Sousa, R. (2003). "Linking Quality Management to Manufacturing Strategy: An Empirical Investigation of Customer Focus Practices." Journal of Operations Management 21(1): $1-18$

[38] Srinivasan, M., Mukherjee, D., \& Gaur, A. (2011). Buyer-supplier partnership quality and supply chain performance: Moderating role of risks, and environmental uncertainty. European Management Journal, 29(4), 260-271.

[39] Szwejczewski, M., Lemke, F., \& Goffin, K. (2005).
Manufacturer-supplier relationships: An empirical study of German manufacturing companies. International Journal of Operations \& Production Management, 25(9), 875-897.

[40] Van T., \& Donk, D. (2004). A critical review of survey-based research in supply chain integration. International Journal of Production Economics, 111(1), 42-55.

[41] Wathne, K. \& Heide, J. (2004). "Relationship Governance in a Supply Chain Network." Journal of Marketing 68(1): 73-89.

[42] Weele, A., Rozemeijer, F., \& Rietveld, G., (2000), "Professionalizing Purchasing Organiztions: Towards a Purchasing Development Model", Avialable at http://www.nyenrode.nl/int/2000, January, 21].

[43] Williamson, E., (1989), "Transaction Cost Economics", Handbook of Industrial Organization, Ed, by R. Schmalensee and R. D. Willig, Volume I, Elsevier, New York, NY.

[44] Williamson, E. (1996). The Mechanisms of Governance. New York, Oxford University Press.

[45] Yin, R. (2003). Case Study Research: Design and Methods (3rd Ed.). Thousand Oaks, CA: Sage Publications Ltd.

[46] Zaheer, A., Gulati, R., \& Nohria, N. (2000). Strategic networks. Strategic management journal, 21(3), 203. 